\title{
Linguistic Intelligibility in International Communication: the Problem of Standards
}

\author{
Marina A. Kapitonova* \\ St. Petersburg State University of Economics \\ 30/32 Nab. kanala Griboedova, St. Petersburg, 191023, Russia
}

Received 20.10.2015, received in revised form 11.02.2016, accepted 17.02.2016

\begin{abstract}
The article mainly focuses on the question of intelligibility concerned as a criterion for the interpretation to be evaluated. The author analyses the role of this linguistic phenomenon within the spheres of international and cross-cultural communication, outlines its main features and, finally, marks its relevance and reasonableness for the use within the contemporary field of translation and translation studies. A special attention is paid towards the problem of standards (ideal models) existing as the starting point for the translation to be analyzed.
\end{abstract}

Keywords: communication, interpretation, symmetry, psycholinguistics, effectiveness, speech.

DOI: 10.17516/1997-1370-2016-9-3-604-611.

Research area: philology.

\section{Introduction}

The current stage of researches in the field of translation and translation studies definitely deserves to be called significant in the sense of a detailed development of categories, aspects, norms and rules. Due to these works we are able to analyse and compare the results of literary and poetry translations, as well as evaluate the quality of, for example, specific translation. Still, there is a question to be asked: since we have at least two major types of translation - written and oral should and (or) can the second one be concerned in the same categories?

One, probably, would answer yes. Nevertheless, on the assumption of existence of so called "static" evaluation categories there also should be opposite ones, or "dynamic", applied directly to the case of interpreting or even simultaneous translation. As we see it, such category should be called intelligibility. The term itself not a new one, but till quite recently it is has been used and concerned within the area of the foreign language teaching and acquisition. In this context we are intrigued by the question, whether this phenomenon can be studied within the crosscultural and international communication and what does it mean "to evaluate intelligibility of translation"?

The phenomenon of linguistic intelligibility: a theoretical arch over the problem

Up to the present moment the linguistic scientific world has built up a huge framework

(C) Siberian Federal University. All rights reserved

* Corresponding author E-mail address: marina.kapitonova@bk.ru 
of conceptions, ideas and definitions. Certainly, some of them may well be called felicitous and, speaking in terms of philosophy, approaching the universalism, whilst others are not. In this sense, the contemporary linguistic science has a lot of different understandings of the notion "communication". Still, all the current definitions boil down to the idea that communication is a process that allows participants (subjects and objects) to exchange information and correctly perceive it through a number of mutual methods (speaking, signing, nonverbal, physical means, eye contact, touches or writing).

Still, let's not go far from the very theme of this article, since the main idea is not a description, criticism or analysis of the terms existed. The purpose of this paper is to concern the process of (classical/traditional) communication through the prism of "to understand-and-to-be-understood". Since so, the most reasonable thing further is to look closer at this phenomenon.

Shall we start from the notion of intelligibility per se. The ancient Latin rule first used in Spinoza's "Political Treatise"-Non indignari, non admirari, sed intelligere - can quite easily be translated into English as "Do not be indignant, admirable, but intelligible". The word intelligibility has Latin origin (intelligibilis $<$ intelligere $=$ to understand). The English language meet it for the first time in the $14^{\text {th }}$ century (Merriam Webster Dictionary) or the Late Middle English (in the sense "capable of understanding") (The Oxford Dictionaries). Another way describing this phenomenon on the abstract basis is its philosophic definition: in this sense, generally speaking, the intelligibility means "what can be comprehended by the human mind in contrast to sense perception". Thus, ancient philosophers (Plato, in particular) referred intelligibility to different domains of logics, i.e. mathematics, forms, logical deduction, dialectical method and etc. Further, Descartes understood intelligibility as "the method of thought thinking about itself" (Descartes, 1998), and Kant compared it to "an a priori knowledge" (as independent from any kind of experience, i.e. senses or mind) (Zambrana, 2015).

Here we are to note, that the biggest part of definitions explained by philosophy or fixed in explanatory dictionaries is reasonably grounded on the principles of universalism, flexibility and availability to be used or understood in any general context. Still, due to the main idea of the article we are to come to some constraints (or restrictions) within the performance sphere of the analyzed notion, i.e. the realm of communication and international communication in particular.

In fact, the precise definition of intelligibility in a speech context is almost the same as many of the mentioned above. Thus, for example, J. Kenworthy implies into this notion the meaning as "to be understood by a listener at a given time in a given situation" (Kenworthy, 1987). Intelligibility is, in fact, the measure of the effectiveness of speech/communication in general: "..an utterance could only be considered intelligible, if it is "effective" (Clatford 1950: 8). In this sense, intelligibility is not mixed with the notion of speech quality. While the first phenomenon describes the amount of different properly used speech elements that are to be recognised, perceived and decoded correctly by a listener, the speech quality is related to the quality of produced speech signals with respect to the amount of probable extra-irregularities. In other words, a synthesized voice message (those which are used in machine translation, travel guides or navigators) is correctly understood by the addressee, but still may be judged to be unnatural or of a low quality - a message that lacks quality may still be intelligible.

It is worth mentioning another focus on the notion of intelligibility in communication proposed by J. Habermas in "Theories of Truth", "The Theory of Communicative Action" and 
many other works. In brief, he describes the theory of speech within its categories, concepts and judgements: in particular, he introduces so called "validity claims" - rightness, truth and intelligibility. (Habermas, 1984: 237) and then makes a clear difference between all of them, including intelligibility. "Truth-claims and rightness-claims function in everyday speech and interaction as claims that they are accepted with an eye to the possibility that if need be they can discursively be made good. Intelligibility, on the contrary as long as communication in general proceeds undisturbed, presents a claim that has already factually been made good; it is not merely a promise" (Habermas, 1987: 126). In other words, Habermas describes intelligibility as the most valid or "primorodial" than others validity claims. Habermas considers, that the fact that there is communication, is itself the validation of a claim to intelligibility: if an utterance was not understandable, so there would be no interaction at all. Still, this point of view seems not to be quite certain: imagine that all utterances are unintelligible, then, quite likely, there would be no interaction or cooperation at all. Anyway, the same situation occurs when we speak on, for example, all rightness claims are violated:

1) I' $m$ going to find this book in the library (a condition over the discourse to ensure whether it is right thing to do or not).

2) I'm going to swim to the library to get this book (the intelligibility of the utterance is needed to be discursively explained).

To conclude, Habermas's view of the intelligibility of an utterance would then make it "a part of our lifeworld, the taken-for-granted background within we act” (Zinkin, 1998: 459).

On the other hand, some scientists claim, that in order to understand the notion "intelligibility" we also are to make a precise difference between three allied ideas: comprehensibility/ interpretability/intelligibility. Relating to this question L.E. Smith has written the following scheme (Smith, 1992):

- Intelligibility = word/utterance recognition;

- Comprehensibility = word/utterance meaning;

- Interpretability = meaning behind word/ utterance;

In fact, he has created a hierarchy of speech main categories and described the process of communication (according to the scheme "recoding - decoding") in a more applied way. Still, H.S. Atechi in "The Intelligibility of Native and Non-Native English Speech" argues that this description seems not to be clear: “... in the process of testing intelligibility, we seem to see no hard and fast rules about where one category ends and another one begins on Smith's categorization". Following this statement, we agree that such taxonomy of categories does not give a clear conception of intelligibility. Since we consider intelligibility to be a complex linguistic phenomenon or as a measure of speech effectiveness/message successfulness, it is not clear then, what is meant by "word/utterance recognition"? Is this a common knowledge of the language? Or the same amount of vocabulary? Should the participants of the interaction use the same, restricted or standardized grammar and lexical structures to be recognized correctly? The answer is rather no, than yes. Undoubtedly, both the speaker and listener should try to use the same linguistic system of signs (the language itself): even in context of the languages contact we fall back upon a translator or interpreter's help as a person who knows the target/source language. Nevertheless, when we speak on intelligibility we are likely to deal with many aspects that go far beyond just word/utterance recognition. It would, probably, be better to say that "word/utterance recognition" is the first stage in the whole process of intelligibility. In 
this sense, let's further try to create the whole scheme of this case (Fig. 1).

As the scheme shows, some features (in particular, interpretability and recognition) are already in the whole concept of intelligibility and concerned as factors for the speech to be intelligible. Still, this can be only one of many other visions on the idea of intelligibility both in the Russian and English sciences due to the fact that its linguistic definition has a lot of aspects to be analyzed within the topical issues of contemporary psycholinguistics.

The concept of intelligibility is quite thoroughly analyzed within the foreign language teaching methodology and so called New Englishes. Here, it would be useful to mention the name of an Indian linguist Braj Kachru, who actually pioneered the term World English. In his work "The Alchemy of English: The Spread, Functions and Models of Non-Native Englishes" he highlights the idea, that due to some complexity of the term intelligibility, it should be linguistically used with no restrictions. This means that although this term is a priori can be found in any pedagogical literature concerning foreign languages learning, acquisition or teaching, there are almost no scientific researches dedicated to intelligibility in the sphere of applied linguistics, cognitive science, cross-cultural and international communication. Secondly, as he points out, "researches are mostly focused on phonetics, specifically on the segmental phonemes...the interference in intelligibility is at other levels, especially in communicative units" (Kachru, 1986). As so, among other quite brilliant ideas concerning New Englishes, he rises up the problem of standards in communication within the terms of intelligibility and interference: "what role does the Native speaker's judgment play in determining the intelligibility of nonnative speech acts that have international functions...?" (Kachru 1986). In fact, describing different points of view on the intelligibility and defining it as an ability to understand and to be understood, as an essential condition of the communication to be conducted thoroughly as well as the "effectiveness" of interaction between the addresser and addressee, we have not yet mentioned one crucial thing. If we consider the intelligibility as the criterion of successful communication (international communication, in particular) we also have to identify some sort of parameters or measurements to evaluate both the intelligibility (or its degree) and the process of communication in general. To maintain this task we are further to describe an "ideal model" or "pattern" of how it should be sounded/ constructed/written and etc. in the most perfect way possible. So in this sense, can there in fact be any standards to determine intelligibility in speech or in different types of speech and communication, as in the case of, for example,

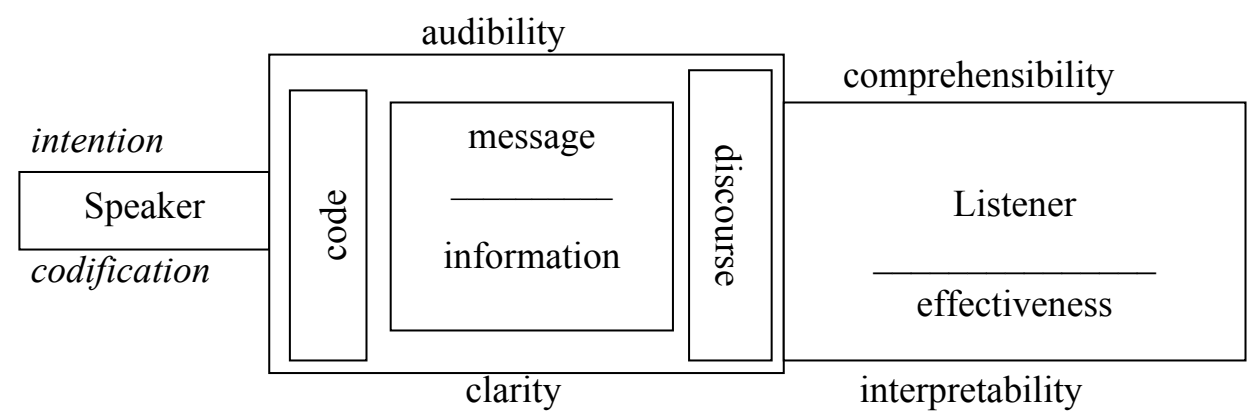

Fig. 1 
simultaneous interpreting? As B. Kachru claims "an idealised Native speaker could serve as a model, but not in the case of non-native varieties, as a native speaker is not a participant in the actual speech situation" (Kachru, 1986).

To draw an intermediate conclusion, we should mention that the intelligibility in communication, and in translation as a form of international communication, is probably should be concerned and evaluated in the terms of the theory of symmetry: in this case the intelligibility itself would mean the symmetry and interference, as the opposite phenomenon, asymmetry. Still, we are to bear in mind, that there are also "middle" components, called dissymmetry and anti-symmetry, which in this very case are consisted of different intelligibility failures. This idea once again evokes the question of whether there can be any standards measuring international communication, or should it remain hypothetical?

\section{The existence of standards in international communication: the role of intelligibility in interpretation}

As it has been claimed in the introduction to the book "Varieties of the Present day English", "...the forces of standardization in a modern technological state are as powerful as they are various... But the language is not realized in the abstract...it is realized as an activity of people. And because the forces of standardization have not yet completely leveled the individuality resulting from genetic make-up and rearing, removed the human impulse to gather in manageably group or nation from nation, language must be as various as the groups who use it and the activities they engaged in" (Bailey, Robinson, 1973: 1 ). Still, why then are we taught as non-native speakers to use so called "standardized English"? Getting closer to the sphere of translation and translation studies there is another question: whether such teaching appears to be useful and effective within the language skills implementation in the real life?

Within the Russian reality which is concerned, of course, as non-native settings for communication, the foreign language learning starts right from the school-years of a child. Generally speaking, (or in the majority of cases) the main idea of such teaching is usually to introduce a child into another system of the language. The word system is quite crucial there, since till recently children have been taught with strong grammar structures, command of lexics and phonetics: indeed, they have mastered two sway English varieties - British English and American English. Nevertheless, in most cases when a child grows up and decides to become a translator or interpreter, or simply wants to dedicate the whole his/her life to foreign languages and cultures, it might be quite hard for them to get used to "real communication", and since so, they are usually confused with what they are to do and to understand.

To describe this problem more thoroughly we should go back to the linguistics and the definition of communication and speech in particular. It has already been recognized by the famous linguist Ferdinand de Saussure (and then followed by Lois Hjelmslev, Albert Sechehaye, A. I. Smirnitskii, L.V. Scherba), that among others, the main features of any speech are: process, motivation, purpose, un-linear, time and spacecoordination, actual, subjective, undirected and etc. Due to these characteristics we can conclude, that the speech actually should not always be "systemized" or "created" in only a strict way possible. Thus, any sort of real communication in each moment (even when we speak about a prepared speech) can change its patterns or structures, the set of words, the word order (with the intention to emphasize some information), syntax, style, register and a lot of other details. As 
we think, the main explanation for such "shifts" is the need for the language to be kept interesting a speaker or listener does not want to be bored with the interaction, quite the opposite, they want to be informed/or to be replied in a desired way in the shortest time possible or in the most compact, but still informative manner. This might be one reason why interpreters or translators (beginners or amateurs) are lost in the process of translation: they need time to perceive the information + decode it + reconstruct it in the target language with the usage of (as they think) strictly correct and only possible grammar, syntax, lexis and etc. As a rule, such a scenario unavoidably leads to the communication failure and halt.

Getting back to what we have called "translation evaluating categories" within the concerned theory, i.e. equivalency, adequacy, identity, symmetry - those which can probably, be called "ideal" or, at least, the maintenance of which can make the result of translation to be perfect or completely successful. Still, they hardly can be applied to the case of interpreting or simultaneous translation: they are more suitable for a detailed comparative analysis of the translated text. As simply as it is, there is no time to think over whether one's interpretation is equivalent and adequate in relation to the source text. So, there should be some other parameters and categories to evaluate the quality of translation. In this context, we believe, that such category is represented by intelligibility within the whole process of communication.

Analyzing a diplomatic speech and its interpretation (in the most complex way possible) as the example of international communication, we share the opinion that interpretation is considered to be successful when the explicit and implicit information is understood by the target audience. Any diplomatic speech in the present time is produced within the framework and rules of public diplomacy: "new public diplomacy $[. .$.$] is official actions conducted by$ governments and private actors [...] based on the conception of "soft power" of information management, state branding, strategic public diplomacy [...]" (Gillboa, 2009); "public diplomacy in its state-based "strategic" guise is a more sophisticated variant of a wellestablished idea-namely that "publics" matter to governments as tools of national foreign policy. In this sense, public diplomacy is hardly a new paradigm of international politics but a strategy located within a hierarchical image of how those politics are configured and the information flows underpinning them. [...] This is redrawing the environment in which much contemporary diplomacy is now conducted, bringing the diplomat's traditional skills to the management of complex policy works" (Hocking, 2005: 41). Consequently, one of the main purposes of such speech is to build a correct and objective image of the state on the international area. In order to fulfil this task, speakers use different linguistic methods, approaches and expressive means in their performance. The speech expressiveness, informative functions, specific discourse and many other aspects make it a real challenge for the interpreter. Texts of diplomatic public speeches, as a rule, are focused on the information delivery and pursuance. Therefore, in such texts informative and expressive functions are recognized as the most important ones. By effective delivering of information and reconstruction of these two functions in the target speech, the interpreter might achieve the desired effect and goal of the whole communication, i.e. to reach the high degree of intelligibility.

Finally, it worth being mentioned that we cannot say something about any standards or ideal patterns (categories) when we speak on the cases of simultaneous interpretation. The only thing we can do in order to understand whether the work is done successfully or not is to measure the 
result of translation by the terms of intelligibility, effectiveness and pragmatics.

\section{Conclusion}

Any successful real communication, first of all, means the absence of interaction breakdowns, which can be caused by different reasons. Presumably, this is the reason why cross-cultural and international intelligibility as the linguistic phenomenon should be taken and developed more seriously in different perspectives: as a two-side process of "delivering" and "perception"; as the process of "decoding" and "understanding"; as the strategy of "hindering" and "enhancing" the desired effect of communication.

That brings us to say that further investigation of this phenomenon together with its opposite side - the process/results of linguistic interference - may serve beneficially to better understanding of translation irregularities and errors made on the psychological/psycholinguistic grounds. The development of a contemporary teaching methodology prepared on the basis of such studies may well help to reduce or eliminate most typical mistakes in the very beginning of a translation career.

\section{References}

Bailey, R. W., Robinson J.L. (1973). Varieties of present-day English. New-York: Macmillan Company.

Clatford, J.C. (1950). Intelligibility, In English language teaching 5 (1).

Descartes, R. (1998). The world and other writings. Cambridge: Cambridge University Press.

Gilboa, E. (2009). Public Diplomacy in the International Age. 2009. Available at http://icp-forum. $\mathrm{gr} / \mathrm{wp} / \mathrm{wp}$-content/uploads/2008/12/gilboa-lecture-athens-jan-2009.pdf

Habermas, J. (1984). The theory of communicative action. Volume 1: Reason and the Rationalization of society. Boston: Beacon Press.

Habermas, J. (1987). The theory of communicative action. Volume 2. Boston: Beacon Press.

Hocking, B. (2005). Rethinking the "New" Public Diplomacy, In The New Public Diplomacy: Soft Power in the International Age. New York: Palgrave Macmillian.

Kachru, B.B. (1986). The alchemy of English: the spread, functions and models of non-native Englishes. Oxford: Pergamon Press.

Kenworthy, J. (1987). Teaching English Pronunciation. London: Longman.

Merriam-Webster: Dictionary and Thesaurus. Intelligibility. Available at: http://www.merriamwebster.com/dictionary/intelligibility

Smith, L.E. (1992). Spread of English and Issues of intelligibility, In The Other Tongue. Chicago, Urbana: University of Illinois Press.

The Oxford Dictionaries. The Oxford Advanced Learner Dictionary. Intelligibility. Available at: http://www.oxforddictionaries.com/ru/определение/learner/intelligibility

Zambrama, R. (2015). Hegel's theory of intelligibility. Chicago: University of Chicago Press.

Zinkin, M. (1998). Habermas on intelligibility, In The Southern Journal of Philosophy (36). 


\section{Лингвистическая понятность \\ в международной коммуникации: \\ проблема определения стандартов}

М.А. Капитонова

Санкт-Петербургский государственный экономический университет

Россия, 191023, Санкт-Петербург, наб. Канала Грибоедова, 30/32

В статье главнымм образом рассматривается вопрос о лингвистической понятности, представленной в качестве критерия оценки устного перевода. Автор анализирует роль данного лингвистического явления в сферах международной и межкультурной коммуникаиии, обозначает его характеристики и признаки и указывает на важность и разумность его дальнейшего использования в области современного практического перевода и переводоведения. Особое внимание уделяется проблеме существования и определения стандартов (идеальных моделей) в качестве точки отсчета для анализа и критики результатов перевода.

Ключевые слова: коммуникация, устный перевод, симметрия, психолингвистика, успешность, речь.

Научная специальность: 10.00.00 - филологические науки. 